\title{
Hubungan antara Nilai C-Reactive Protein, Immature To Total Neutrophil Ratio, dan Red Cell Distribution Width dengan Kejadian Sepsis Neonatorum Bayi Prematur
}

Fouad Hakiem, Tetty Yuniati, Susi Susanah

Departemen Ilmu Kesehatan Anak Fakultas Kedokteran Universitas Padjadjaran, RSUP Dr. Hasan Sadikin, Bandung

Latar belakang. Bayi prematur rentan terhadap infeksi yang berisiko sepsis akibat sistem imun yang belum sempurna. Deteksi dini sepsis neonatorum dapat dilakukan dengan menggunakan sistem penilaian modifikasi Tollner yang berdasarkan penilaian klinis dan parameter laboratorium, seperti C-Reactive Protein (CRP), rasio Immature to Total Neutrophil (rasio I/T), dan Red Cell Distribution Width (RDW). Pemeriksaan RDW menunjukkan heterogenitas eritrosit akibat detruksi eritrosit oleh suatu proses infeksi.

Tujuan. Mengetahui hubungan antara nilai CRP, rasio I/T, dan RDW dengan kejadian sepsis neonatorum bayi prematur.

Metode. Studi kasus kontrol menggunakan data sekunder rekam medis dengan subjek penelitian bayi prematur usia gestasi 28-<37 minggu yang dirawat di ruang neonatus Rumah Sakit Hasan Sadikin (RSHS) periode Desember 2018-Mei 2019. Kelompok kasus adalah bayi prematur sepsis, sedangkan kelompok kontrol adalah bayi prematur sakit tidak sepsis yang dilakukan pemeriksaan CRP, rasio I/T, dan RDW. Data dianalisis secara bivariat dan multivariat dengan regresi logistik menggunakan program SPSS dan STATA. Hasil. Penelitian ini melibatkan 30 bayi prematur sepsis dan 30 bayi prematur tidak sakit (kontrol). Analisis bivariat menunjukkan nilai CRP dan rasio IT berhubungan bermakna terhadap kejadian sepsis dengan masing-masing $\mathrm{p}<0,001$ dan $\mathrm{p}<0,011$. Analisis multivariat dengan regresi logistik menunjukkan nilai CRP $>0,64 \mathrm{mg} / \mathrm{dL}$ berisiko 32 kali terhadap kejadian sepsis $(\mathrm{p}<0,001)$ dibandingkan rasio I/T >0,119 dan RDW >18,7\% yang masing-masing 3,2 kali ( $\mathrm{p}=0,446)$ dan 0,9 kali $(\mathrm{p}=0,947)$ terhadap kejadian sepsis.

Kesimpulan. Pemeriksaan CRP merupakan pemeriksaan yang lebih baik dalam membantu menegakkan diagnosis sepsis neonatorum bayi prematur dibandingkan pemeriksaan rasio I/T dan RDW. Sari Pediatri 2019;21(4):218-25

Kata kunci: sepsis neonatorum, bayi prematur, CRP, rasio I/T, RDW

\section{The Association Between C-Reactive Protein, Immature to Total Neutrophil Ratio, and Red Cell Distribution Width with Neonatal Sepsis in Premature Infant}

Fouad Hakiem, Tetty Yuniati, Susi Susanah

Background. Premature infants are susceptible to infection at risk of sepsis due to their immature immune system. Early detection of neonatal sepsis using Tollner scoring system is based on clinical and laboratory findings, such as C-Reactive Protein (CRP), Immature to Total Neutrophil ratio (I/T ratio), and Red Cell Distribution Width (RDW). RDW is a marker of red blood cell heterogeneity caused by destruction due to infection process.

Objective. To determine the association between CRP, I/T ratio, and RDW value with sepsis incidence in premature infants.

Methods. This is a case-control study through review of medical records of infants with gestational age of $28-<37$ weeks hospitalized in neonatal wards of Hasan Sadikin Hospital from December 2018 to May 2019. Those diagnosed with sepsis are considered as cases, those without sepsis as control group. All subjects underwent CRP, I/T ratio, and RDW examinations during hospitalization. Data analysis included bivariate and multivariate analysis with logistic regression by SPSS and STATA.

Results. We included 30 premature infants with sepsis (case group) and 30 premature infants without sepsis (control group). Bivariate analysis showed CRP and I/T ratio was associated significantly with sepsis ( $\mathrm{p}<0.001$ and $\mathrm{p}<0.011$, respectively). Multivariate analysis with logistic regression showed CRP value $>0.64 \mathrm{mg} / \mathrm{dL}$ possessed 32 times higher risk of conducting sepsis $(\mathrm{p}<0.001)$ than $\mathrm{I} / \mathrm{T}$ ratio $>0.119$ and RDW $>18.7 \%$ (3.2 times, $\mathrm{p}=0.446$ and 0.9 times, $\mathrm{p}=0.947$, respectively).

Conclusion. CRP is a better examination in establishing definitive diagnosis of neonatal sepsis compared to I/T ratio and RDW. Sari Pediatri 2019;21(4):218-25

Keywords: neonatal sepsis, premature infant, CRP, I/T Ratio, RDW

Alamat korespondensi: Fouad Hakiem. Departemen Ilmu Kesehatan Anak Fakultas Kedokteran Universitas Padjadjaran/RSUP Dr Hasan Sadikin Bandung, Indonesia. Jalan Pasteur No 38 Bandung 40151. E-mail: f88hakiem@gmail.com 
Fouad Hakiem dkk: Hubungan antara nilai CRV, rasio I/T, dan RDW dengan kejadian sepsis neonatorum bayi prematur

S epsis neonatorum merupakan infeksi sistemik yang terjadi pada bayi dalam 28 hari pertama kehidupan dan merupakan penyebab utama morbiditas dan mortalitas pada bayi baru lahir., ${ }^{1,2}$ Bayi prematur sangat rentan terhadap paparan organisme virulen yang dapat menyebabkan infeksi. Kerentanan ini disebabkan oleh fungsi sistem imun yang belum bekerja optimal. ${ }^{3}$ Pada bayi prematur dijumpai kadar eritropoetin yang sangat rendah. Hal ini menjelaskan bahwa penurunan eritropoesis bayi prematur terjadi akibat produksi eritropoetin yang tidak adekuat. Pada waktu lahir, volume eritrosit lebih rendah dengan masa hidup eritrosit yang lebih pendek (35-50 hari). Semua bayi baru lahir akan mengalami penurunan hemoglobin pada minggu pertama kehidupan, terutama bayi prematur yang mengalami penurunan hemoglobin lebih awal dan lebih cepat. ${ }^{4}$ Pada bayi prematur, sepsis terjadi pada 16-30\% dan sekitar 50\% di antaranya terjadi pada bayi dengan berat badan di bawah 1000 gram. ${ }^{5}$

Sepsis neonatorum pada bayi prematur menyebabkan morbiditas yang lebih kompleks. Gejala yang ditemukan meliputi ikterus, distress napas, kejang, termolabil, hipotensi, hipoglikemia, trombositopenia, bahkan koagulasi intravaskular diseminata (KID). ${ }^{6}$ Diagnosis sepsis neonatorum dapat ditegakkan melalui penggunaan berbagai macam skoring, di antaranya modifikasi Tollner yang merupakan sistem skoring yang sering digunakan yang penilaiannya berdasarkan keadaan bayi secara klinis dan hasil laboratorium. Penggunaan skoring ini dapat membantu dalam deteksi awal sepsis neonatorum. ${ }^{7,8}$

Diagnosis pasti sepsis neonatorum ditegakkan atas dasar ditemukannya organisme dalam pemeriksaan kultur darah, tetapi prosedur ini membutuhkan waktu yang relatif lama, yaitu sekitar 2-8 hari. Oleh karena itu, berbagai pemeriksaan laboratorium lain diperlukan untuk membantu menegakkan diagnosis sepsis sejak dini termasuk sepsis neonatorum. Saat ini, pemeriksaan laboratoriun yang digunakan untuk penilaian diagnosis cepat sepsis adalah $C$-Reactive Protein (CRP) dan rasio Immature to Total Neutrophil (rasio I/T) yang sudah masuk skoring modifikasi Tollner. Pemeriksaan laboratorium lain yang dapat digunakan dalam mendiagnosis sepsis neonatorum adalah Red Cell Distribution Width (RDW). Pada sepsis, terjadi peningkatan destruksi eritrosit dan produksi eritrosit sehingga meningkatkan populasi heterogenisitas eritrosit yang ditunjukkan dengan peningkatan nilai RDW. ${ }^{2,9}$
C-reactive protein merupakan salah satu pemeriksaan darah yang mengukur jumlah protein yang dihasilkan hati sebagai respons terhadap reaksi inflamasi dan kerusakan jaringan. ${ }^{10}$ Rasio I/T yang dihitung berdasarkan perbandingan antara neutrofil imatur terhadap jumlah total neutrofil pada pemeriksaan apus darah tepi. Neutrofil imatur yang ditemukan pada pemeriksaan apus darah tepi biasanya dapat ditemukan pada saat infeksi dan septikemia. ${ }^{11}$ Bila rasio neutrofil imatur dengan neutrofil total $>0,16$, hal ini menunjukkan infeksi bakteri. ${ }^{12}$

Red cell distribution width merupakan parameter hematologi yang menunjukkan heterogenitas ukuran atau volume eritrosit perifer yang nilainya diperoleh melalui histogram eritrosit. ${ }^{13}$ Pada sepsis, terjadi peningkatan destruksi eritrosit dan produksi eritrosit sehingga meningkatkan populasi heterogenisitas eritrosit yang ditunjukkan dengan peningkatan nilai RDW sehingga tingginya nilai RDW berhubungan dengan tingkat keparahan sepsis dan merupakan prediktor kuat penyebab mortalitas pada bayi dengan sepsis neonatorum. ${ }^{14}$

Pemeriksaan CRP memerlukan biaya yang besar sehingga pada penelitian ini diharapkan mendapatkan alternatif pemeriksaan darah selain CRP, yaitu rasio I/T dan RDW yang menunjang diagnosis sepsis neonatorum lebih dini dengan biaya yang lebih ekonomis. Dengan demikian, beberapa pendekatan termasuk sistem penilaian dapat diimplementasikan untuk mengefisiensikan diagnosis sepsis neonatorum. ${ }^{?}$ Hingga saat ini penelitian yang menghubungkan sepsis neonatorum pada bayi prematur dengan parameter laboratorium berupa CRP, rasio I/T, dan RDW belum pernah dilakukan.

\section{Metode}

Penelitian ini merupakan studi kasus kontrol yang menilai hubungan antara CRP, rasio I/T, dan RDW dengan kejadian sepsis neonatorum bayi prematur usia gestasi $28-<37$ minggu yang dirawat di ruang perawatan neonatus Anthurium Rumah Sakit dr. Hasan Sadikin (RSHS) periode Desember 2018-Mei 2019. Penelitian ini telah mendapat persetujuan Komite Etik Penelitian Kesehatan Fakultas Kedokteran Universitas Padjadjaran-RSHS. Ukuran sampel ditentukan berdasarkan tingkat kepercayaan 95\% dan kekuatan uji 95\%. Pemilihan subjek untuk kelompok kasus 
dipilih secara random dari database yang terdaftar pada komputer Asuhan Maternal Pediatrik (AMP) ruang Anthurium sesuai dengan kriteria penelitian sampai dengan jumlah subjek terpenuhi.

Selanjutnya dilakukan penilaian sepsis terhadap subjek dengan menggunakan skoring modifikasi Tollner berdasarkan data yang didapatkan dari rekam medis dengan kecurigaan awal sepsis. Kriteria inklusi adalah bayi prematur sepsis maupun tidak sepsis usia gestasi $28-<37$ minggu yang telah dilakukan pemeriksaan CRP, rasio I/T, dan RDW. Kriteria eksklusi adalah bayi dengan kelainan kongenital mayor, asfiksia berat, anemia hemolitik, dan yang pernah mendapatkan transfusi darah. Berdasarkan hasil penilaian skor sepsis modifikasi Tollner, subjek dibagi menjadi dua kelompok, yaitu kelompok sepsis bila skor $>10$ dan kelompok kontrol bila skor $<5$. Subjek yang dimasukkan kelompok kontrol dipilih dengan cara mencocokkan (matching) berdasarkan usia gestasi, berat badan, dan jenis kelamin.

Hasil pemeriksaan laboratorium yang didapatkan dari rekam medis berupa nilai CRP, rasio I/T, dan RDW. Nilai CRP dikategorikan sebagai CRP normal dan CRP meningkat sesuai dengan nilai normal CRP berdasarkan usia gestasi dan onset sepsis. Nilai normal CRP bayi cukup bulan dan prematur terlampir. ${ }^{15}$ Nilai rasio I/T dikategorikan sebagai normal dan meningkat (nilai normal rasio I/T <0,2). ${ }^{11}$ Nilai RDW dikategorikan sebagai RDW normal dan meningkat, berdasar nilai normal RDW sesuai usia gestasi. Nilai normal RDW-CV bayi cukup bulan dan prematur terlampir. ${ }^{16}$

Data yang terkumpul diolah dan dianalisis secara bivariat dan multivariat (menggunakan regresi logistik). Data kategorik disajikan dalam jumlah dan persentase, sementara data numerik disajikan dengan ukuran statistik rerata dan simpang baku jika terdistribusi normal, serta median dan rentang jika tidak terdistribusi normal.

Uji normalitas data untuk data numerik dilakukan dengan uji Shapiro-wilk. Data dinyatakan berdistribusi normal jika nilai signifikansi $\mathrm{p}>0,05$. Kelompok data kategorik dianalisis dengan chi-square, jika ada nilai ekspektasi $\leq 5$ maka menggunakan uji exact Fisher. Uji hipotesis dalam penelitian ini adalah independent t test jika data terdistribusi normal dengan membandingkan rerata di kedua kelompok dan uji Mann Whitney jika data tidak terdistribusi normal untuk membandingkan median kedua kelompok.
Untuk menentukan cut off point CRP, rasio I/T, dan RDW digunakan perhitungan berdasar kurva Receiver Operating Characteristic (ROC). Nilai Area Under Curve (AUC) menentukan kekuatan diagnostik masing-masing variabel terhadap kejadian sepsis. Untuk menentukan seberapa besar pengaruh CRP, rasio I/T, dan RDW terhadap kejadian sepsis neonatorum bayi prematur maka masing-masing variabel dilihat berdasarkan adjusted odds ratio (OR) dengan interval kepercayaan $95 \%$. Untuk mengetahui pengaruh secara simultan ketiga parameter laboratorium tersebut, digunakan analisis regresi logistik ganda. Analisis data akan dilakukan menggunakan program IBM SPSS dan STATA 14.2 untuk sistem operasi Windows versi 25.0. Semua uji statistik akan dilakukan pada taraf signifikansi 0,05 .

\section{Hasil}

Tiga puluh subjek bayi sepsis yang terdiri dari 12 bayi perempuan dan 18 bayi laki-laki dengan berat badan lahir berkisar antara 950 sampai dengan 2650 gram dengan rerata 1597 gram, sedangkan dari 30 subjek bayi yang tidak sepsis terdapat $12(40 \%)$ bayi perempuan dan 18 (60\%) laki-laki dengan berat badan lahir berkisar antara 940 sampai 2670 gram dengan rerata 1602 gram. Usia gestasi terbanyak terdapat pada kelompok usia gestasi $28-31$ minggu, yaitu 40\%. Karakteristik jenis kelamin, berat badan lahir, dan usia gestasi pada kelompok sepsis dengan kelompok tidak sepsis tidak menunjukkan adanya perbedaan bermakna dengan nilai masing-masing $\mathrm{p}=1, \mathrm{p}=0,966$, dan 0,946(p>0,05).

Nilai CRP pada pasien sepsis memiliki median lebih tinggi $(6,41 \mathrm{mg} / \mathrm{dL}$ versus $0,17 \mathrm{mg} / \mathrm{dL})$, berbeda bermakna secara statistik dengan nilai $\mathrm{p}<0,001$ $(\mathrm{p}<0,05)$. Pasien sepsis memiliki median rasio I/T lebih tinggi $(0,034$ vs 0,01$)$ tidak berbeda secara bermakna ( $\mathrm{p}=0,169)$. Median nilai RDW pada pasien sepsis juga lebih tinggi ( $17 \%$ vs $16,9 \%$ ), tidak berbeda bermakna antara kedua kelompok subjek dengan nilai $\mathrm{p}=0,636$ seperti tertera pada Tabel 2.

Meskipun pemeriksaan CRP dan rasio I/T merupakan bagian dalam penilaian skoring modifikasi Tollner sebagai penanda umum infeksi, hal ini tidak memengaruhi hasil analisis penelitian karena pada kelompok kontrol terdapat satu subjek $(3,3 \%)$ yang mengalami peningkatan nilai CRP sehingga penelitian 
Fouad Hakiem dkk: Hubungan antara nilai CRV, rasio I/T, dan RDW dengan kejadian sepsis neonatorum bayi prematur

Tabel 1. Karakteristik subjek penelitian pada bayi prematur sepsis dan tidak sepsis

\begin{tabular}{lccc}
\hline Karakteristik & \multicolumn{2}{c}{ Kejadian sepsis } & \multirow{2}{*}{ Nilai $\left.\mathrm{p}^{*}\right)$} \\
\cline { 2 - 3 } & $\begin{array}{c}\text { Sepsis } \\
(\mathrm{n}=30)\end{array}$ & $\begin{array}{c}\text { Tidak sepsis } \\
(\mathrm{n}=30)\end{array}$ & \\
\hline Jenis kelamin, n (\%) & $18(60,0)$ & $18(60,0)$ & $1,000^{\mathrm{a}}$ \\
$\quad$ Laki-laki & $12(40,0)$ & $12(40,0)$ & \\
$\quad$ Perempuan & & & \\
Berat badan lahir (gram) & $1597(464)$ & $1602(463)$ & $0,966^{\mathrm{b}}$ \\
$\quad$ Rerata (SD) & $950-2650$ & $940-2670$ & \\
$\quad$ Rentang & & & \\
& & & \\
Usia gestasi (minggu), n (\%) & $12(40,0)$ & $12(40,0)$ & $0,946^{\mathrm{a}}$ \\
$28-31$ & $9(30,0)$ & $8(26,7)$ & \\
$32-34$ & $9(30,0)$ & $10(33,3)$ & \\
$35-<37$ & &
\end{tabular}

Keterangan: ${ }^{*}$ ) analisis menggunakan uji ${ }^{\mathrm{a} C h i-s q u a r e,}{ }^{\mathrm{b}}$ independent $t$ testt, SD: standar deviasi

Tabel 2. Perbandingan nilai CRP, Rasio I/T, dan RDW antara bayi prematur sepsis dan tidak sepsis

\begin{tabular}{lccc}
\hline \multirow{2}{*}{ Karakteristik } & \multicolumn{2}{c}{ Kejadian sepsis } & \multirow{2}{*}{ Nilai ${ }^{*}{ }^{*}$} \\
\cline { 2 - 3 } $\begin{array}{c}\text { CRP }(\mathrm{mg} / \mathrm{dL}) \\
\text { Median } \\
\text { Rentang }\end{array}$ & $\begin{array}{c}\text { Sepsis } \\
(\mathrm{n}=30)\end{array}$ & $\begin{array}{c}\text { Tidak sepsis } \\
(\mathrm{n}=30)\end{array}$ & $<0,001^{*}$ \\
$\begin{array}{l}\text { Rasio I/T } \\
\text { Median }\end{array}$ & $0,04-25,05$ & $0,00-10,90$ & \\
Rentang & 0,034 & & 0,169 \\
RDW (\%) & $0,000-0,498$ & $0,000-0,119$ & \\
Median & & & 0,636 \\
Rentang & 17,0 & 16,9 & 0,636 \\
\hline
\end{tabular}

Keterangan: ${ }^{*}$ ) berdasarkan uji Mann-Whitney karena data tidak berdistribusi normal

ini dapat dilanjutkan dengan menentukan nilai cut off optimal setiap variabel menggunakan kurva ROC.

Dari kurva pada Gambar 1 diperoleh nilai cut off optimal kadar CRP yang dapat dipakai prediktor sepsis pada bayi prematur, yaitu $0,64 \mathrm{mg} / \mathrm{dL}$ dengan besar sensitivitas $90 \%$ dan spesifisitas $86,7 \%$. Nilai cut off optimal untuk rasio I/T yang adalah 0,119 dengan sensitivitas 23,3\% dan spesifisitas $100 \%$. Nilai cut off optimal RDW yang diperoleh adalah $18,7 \%$ dengan sensitivitas 33,33\% dan spesifisitas 83,3\%.

Tabel 3 menunjukkan hasil nilai cut off CRP, Rasio I/T, dan RDW dengan kejadian sepsis pada bayi prematur berdasarkan analisis ROC. Didapatkan nilai
AUC untuk nilai CRP terhadap kejadian sepsis bayi prematur adalah 0,907. Hal ini menunjukkan CRP memiliki kekuatan diagnostik yang tinggi. Nilai AUC rasio I/T dengan kejadian sepsis pada bayi prematur didapatkan 0,599, yang menunjukkan bahwa rasio I/T memiliki kekuatan diagnostik sangat lemah terhadap kejadian sepsis. Untuk nilai RDW didapatkan nilai AUC sebesar 0,536. Nilai AUC tersebut menunjukkan bahwa nilai RDW memiliki kekuatan diagnostik yang sangat lemah. Hasil analisis hubungan antara CRP, rasio I/T, dan RDW berdasarkan nilai cut off terhadap kejadian sepsis neonataorum tertera pada Tabel 4.

Pada Tabel 4, setelah nilai CRP, rasio I/T, dan nilai 
Fouad Hakiem dkk: Hubungan antara nilai CRV, rasio I/T, dan RDW dengan kejadian sepsis neonatorum bayi prematur

Tabel 3. Nilai cut off CRP, rasio I/T dan RDW berdasarkan analisis ROC

\begin{tabular}{llll}
\hline Variabel & Nilai AUC & Nilai $\mathrm{p}$ & Nilai cut off point \\
\hline CRP $(\mathrm{mg} / \mathrm{dL})$ & 0,907 & $<0,001^{*}$ & $>0,64$ \\
Rasio I/T & 0,599 & 0,164 & $>0,119$ \\
RDW $(\%)$ & 0,536 & 0,641 & $>18,7$ \\
\hline
\end{tabular}

Keterangan: $\mathrm{AUC}=$ Area Under Curve, $\mathrm{ROC}=$ Receiver Operating Characteristic

Tabel 4. Hubungan antara CRP, rasio I/T dan RDW

\begin{tabular}{|c|c|c|c|c|}
\hline \multirow[b]{2}{*}{ Variabel } & \multicolumn{2}{|c|}{ Sepsis } & \multirow[b]{2}{*}{ Nilai p } & \multirow[b]{2}{*}{ OR (IK 95\%) } \\
\hline & $\begin{array}{c}\text { Positif } \\
(\mathrm{n}=30)\end{array}$ & $\begin{array}{l}\text { Negatif } \\
(\mathrm{n}=30)\end{array}$ & & \\
\hline \multicolumn{5}{|c|}{ CRP, frekuensi (\%) } \\
\hline$>0,64 \mathrm{mg} / \mathrm{dL}$ & $27(90,0)$ & $4(13,3)$ & $<0,001^{*}$ & $58,5(11,9-287,1)$ \\
\hline$\leq 0,64 \mathrm{mg} / \mathrm{dL}$ & $3(10,0)$ & $26(86,7)$ & & \\
\hline \multicolumn{5}{|c|}{ Rasio I/T, frekuensi (\%) } \\
\hline$>0,119$ & $7(23,3)$ & $0(0,0)$ & $0,011^{*}$ & $19,5(1,1-358,4)$ \\
\hline$\leq 0,119$ & $23(76,7)$ & $30(100,0)$ & & \\
\hline \multicolumn{5}{|c|}{ RDW, frekuensi (\%) } \\
\hline$>18,7 \%$ & $10(33,3)$ & $5(16,7)$ & 0,136 & $2,5(0,7-8,5)$ \\
\hline$\leq 18,7 \%$ & $20(66,7)$ & $25(83,3)$ & & \\
\hline
\end{tabular}

Keterangan: OR: Odds ratio (IK: interval konfidensi 95\%)

Tabel 5. Analisis multivariat CRP, rasio I/T dan RDW

\begin{tabular}{lcc}
\hline Variabel (nilai cut off point) & Adjusted OR (IK 95\%) & Nilai p \\
\hline CRP $(>0,64 \mathrm{mg} / \mathrm{dL})$ & $32,0(6,9-147,9)$ & $<0,001^{*}$ \\
Rasio I/T $(>0,119)$ & $3,2(0,2-66,6)$ & 0,446 \\
RDW $(>18,7 \%)$ & $0,9(0,2-5,6)$ & 0,947 \\
\hline
\end{tabular}

Keterangan: OR: Odds ratio (IK: interval kepercayaan 95\%)

RDW dikelompokkan menjadi dikotom dengan batas cut off masing-masing, didapatkan nilai signifikansi dan odd ratio untuk tiap variabel. Odds ratio (OR) yang menggambarkan hubungan antara nilai CRP dengan kejadian sepsis adalah 58,5 dengan IK 95\% 11,9-287,1. Hubungan ini bermakna secara statistik bermaknsa $(\mathrm{p}<0,001)$. Hubungan rasio I/T dengan kejadian sepsis memiliki OR 19,5 dengan IK 95\% 1,1358,4 , bermakna secara statistik dengan nilai $\mathrm{p}=0,011$ $(\mathrm{p}<0,05)$. Nilai RDW tidak memiliki hubungan yang bermakna dengan kejadian sepsis dengan nilai $\mathrm{p}=0,136$ ( $p>0,05)$, digambarkan dengan OR 2,5 dan IK 95\% $0,7-8,5$. Analisis multivariat dengan melibatkan ketiga variabel bersama-sama dilakukan menggunakan regresi logistik ganda dengan metode enter (Tabel 5).

Analisis multivariat mendapatkan bahwa hanya CRP yang memiliki pengaruh bermakna terhadap kejadian sepsis $(\mathrm{p}<0,001)$ dengan adjusted OR sebesar 32,0. Variabel lain, rasio I/T dan nilai RDW tidak memiliki pengaruh yang bermakna terhadap kejadian sepsis dengan nilai $\mathrm{p}=0,446$ dan $\mathrm{p}=0,947$ secara berurutan $(\mathrm{p}>0,05)$.

Pada penelitian ini didapatkan hubungan bermakna antara nilai CRP dengan kejadian sepsis neonatorum sedangkan nilai RDW tidak memiliki hubungan bermakna dengan kejadian sepsis neonatorum. Pada awalnya, nilai rasio I/T (Tabel 4) masih menunjukkan hubungan bermakna terhadap kejadian sepsis, tetapi setelah dilakukan analisis multivariat dengan regresi logistik, hubungan ini tidak bermakna. Nilai CRP $>0,64 \mathrm{mg} / \mathrm{dL}$ memiliki kemungkinan 32 kali lebih tinggi untuk mengalami sepsis dibandingkan dengan nilai $C R P \leq 0,64 \mathrm{mg} / \mathrm{dL}$.

\section{Pembahasan}

Pemeriksaan laboratorium yang selama ini menjadi baku emas diagnosis sepsis neonatorum adalah hasil kultur darah yang memiliki sensitivitas tinggi, tetapi 
memerlukan waktu lama, yaitu sekitar 2-8 hari. Sementara dengan kondisi optimal sekalipun, hanya $5-10 \%$ pasien yang secara klinis sepsis dapat dikonfirmasi bahwa penderita benar-benar dinyatakan sepsis. ${ }^{6}$ Pemeriksaan parameter hematologi menjadi alternatif yang perlu dipertimbangkan untuk dapat dijadikan parameter prediksi kejadian sepsis neonatorum.

Pada penelitian ini didapatkan bahwa median CRP pada bayi prematur sepsis lebih tinggi dibandingkan dengan bayi prematur tidak sepsis. Selain itu, penelitian ini juga mendapatkan bahwa CRP dapat dijadikan penanda yang baik untuk mendeteksi 90\% kejadian sepsis dengan cut off $0,64 \mathrm{mg} / \mathrm{dL}$. Terbukti bahwa nilai CRP $>0,64 \mathrm{mg} / \mathrm{dL}$ berpotensi $32 \mathrm{kali}$ untuk terjadi sepsis. Hasil ini serupa dengan dengan hasil penelitian Cosar $\mathrm{dkk}^{10}$ di Turki pada tahun 2017 yang melaporkan bahwa nilai CRP bayi sepsis lebih tinggi $(21,2 \pm 19,06 \mathrm{mg} / \mathrm{L})$ jika dibandingkan dengan kelompok kontrol. Penelitian lain mengenai CRP dilakukan oleh Loni $\mathrm{dkk}^{17}$ di India pada tahun 2010 yang melaporkan bahwa CRP meningkat 66,7\% pada kasus sepsis neonatorum awitan dini.

$C$-reactive protein merupakan salah satu protein fase akut yang dihasilkan hati sebagai akibat proses infeksi dan reaksi inflamasi yang menimbulkan kerusakan jaringan sehingga dapat menjadi penanda yang baik untuk adanya infeksi bakteri pada neonatus. ${ }^{8}$ Sepsis timbul sebagai suatu kegagalan regulasi respons pejamu antara mekanisme proinflamasi dan antiinflamasi. ${ }^{18}$ Pada sepsis, terjadi pelepasan mediator inflamasi seperti interleukin-6 (IL-6), tumour necrosis factor-alfa $(\mathrm{TNF}-\alpha)$, dan sitokin proinflamasi. Mediator-mediator ini menyebabkan protein fase akut yang dihasilkan di hati, seperti CRP menjadi meningkat. ${ }^{8}$

Bayi prematur sepsis memiliki median rasio I/T lebih besar, yaitu 0,034 dibandingkan bayi tidak sepsis yaitu 0,01 , tetapi analisis statistik tidak menunjukkan perbedaan bermakna. Analisis dengan kurva ROC juga mendapatkan bahwa berdasarkan nilai AUC, rasio I/T bukan merupakan penanda baik untuk mendeteksi kejadian sepsis neonatorum. Hasil ini berbeda dengan penelitian di India oleh Desai $\mathrm{dkk}^{2}$ pada tahun 2014 yang melaporkan bahwa $70 \%$ dari 100 bayi dengan manifestasi klinis sepsis memiliki rasio I/T $>0,2$ dan penelitian lain di Indonesia oleh Darni $\mathrm{dkk}^{19}$ pada tahun 2011 mendapatkan sensitivitas dan spesifisitas dengan rasio I/T $>0,2$ masing-masing $88,46 \%$ dan $81,48 \%$.

Rasio I/T merupakan perbandingan antara neutrofil imatur terhadap jumlah total neutrofil pada apus darah tepi. Bila rasio neutrofil imatur dengan neutrofil total $>0,16$, maka hal ini menunjukkan adanya infeksi bakteri. ${ }^{3}$ Pada keadaan infeksi bakteri, neutrofil merupakan bagian dari sel leukosit yang berfungsi sebagai sistem pertahanan tubuh dalam melawan benda asing dari luar tubuh termasuk infeksi. Sepsis yang diawali dengan infeksi bakteri juga dapat menimbulkan pelepasan neutrofil ke dalam aliran darah. Proses perjalanan infeksi akut akan meningkatkan pelepasan leukosit, secara umum diawali dengan pembentukan neutrofil imatur sehingga dapat terjadi peningkatan neutrophil imatur yang disebut Shift To the Left (STTL). Semakin tinggi kejadian STTL menandakan bahwa infeksi yang terjadi semakin berat. ${ }^{13,20}$

Pemeriksaan RDW didapatkan median yang lebih tinggi, yaitu 17\% dibandingkan bayi tidak sepsis dengan median RDW 16,9\%, tetapi secara statistik tidak berbeda bermakna. Analisis dari masing-masing nilai AUC, yaitu CRP 0,907 memiliki nilai diagnostik yang kuat untuk mendiagnosis sepsis. Sementara nilai AUC rasio I/T dan RDW masing-masing 0,599 dan 0,536, menunjukkan bahwa nilai rasio I/T dan RDW bukan merupakan penanda yang baik untuk mendeteksi kejadian sepsis karena memiliki kekuatan diagnostik yang sangat lemah. Hasil ini berbeda dengan penelitian RDW terhadap bayi prematur dan cukup bulan yang dilakukan oleh Saleh dkk ${ }^{21}$ di Mesir tahun 2017 yang melaporkan perbedaan bermakna antara neonatus sepsis dengan rerata RDW 18,35\% jika dibandingkan kelompok kontrol. Penelitian lain oleh Martin $\mathrm{dkk}^{22}$ di India tahun 2018 melaporkan nilai RDW neonatus sepsis cukup bulan dan prematur meningkat bermakna dibandingkan kelompok kontrol. Penelitian RDW ini berhubungan dengan nilai hemoglobin, bahwa semua bayi baru lahir akan mengalami penurunan hemoglobin pada minggu pertama kehidupan terutama bayi prematur yang mengalami penurunan hemoglobin lebih awal dan lebih cepat. Hal ini menunjukkan bahwa usia gestasi bayi prematur berhubungan dengan peningkatan nilai RDW. ${ }^{4}$

Perbedaan hasil penelitian ini disebabkan terdapat perbedaan dalam menentukan kriteria seleksi untuk kelompok kontrol. Pada penelitian Martin $\mathrm{dkk}^{22} \mathrm{di}$ India tahun 2018, kelompok kontrol merupakan bayi yang benar-benar sehat, sedangkan bayi prematur sehat yang berada di ruang neonatus Anthurium RSHS tidak dilakukan pemeriksaan laboratorium darah secara rutin. 
Fouad Hakiem dkk: Hubungan antara nilai CRV, rasio I/T, dan RDW dengan kejadian sepsis neonatorum bayi prematur

Keseluruhan hasil penelitian ini mendukung beberapa hasil penelitian sebelumnya mengenai kegunaan parameter CRP pada sepsis neonatorum, khususnya pada bayi prematur untuk membantu diagnosis awal sepsis. Sementara rasio I/T dan nilai RDW tidak menunjukkan pengaruh yang bermakna. Hal ini dapat dijadikan pertimbangan para klinisi untuk menggunakan parameter CRP sebagai pemeriksaan awal untuk mendeteksi sepsis neonatorum lebih dini, sementara menunggu hasil pemeriksaan kultur darah.

Beberapa fasilitas kesehatan tingkat dua di Indonesia telah memiliki sarana pemeriksaan laboratorium berupa CRP, rasio I/T, dan RDW. Pemeriksaan tersebut sesuai untuk neonatus sakit kritis maupun bayi berat badan lahir sangat rendah (BBLSR) dengan volume darah relatif sedikit dan terbatas untuk pemeriksaan laboratorium..$^{23}$

Penelitian ini hanya menilai hubungan parameter CRP, rasio I/T, dan RDW dengan kejadian sepsis. Masih ada parameter nilai laboratorium lain yang juga dapat diperhitungkan akan memengaruhi kejadian sepsis neonatorum. Keterbatasan lainnya adalah kontrol yang diambil bukan berdasarkan kriteria bayi prematur yang sehat. Disarankan untuk penelitian selanjutnya dilakukan dengan subjek kontrol bayi prematur sehat.

\section{Kesimpulan}

Pemeriksaan CRP merupakan alternatif pemeriksaan yang lebih baik dalam membantu menegakkan diagnosis sepsis neonatorum dibandingkan pemeriksaan rasio I/T dan RDW.

\section{Daftar pustaka}

1. Tewabe T, Mohammed S, Tilahun Y, Melaku B, Fenta M, Dagnaw T, dkk. Clinical outcome and risk factors of neonatal sepsis among neonates in Felege Hiwot referral Hospital, Bahir Dar, Amhara Regional State, North West Ethiopia 2016: a retrospective chart review. BMC Res Notes 2017;10:265.

2. Desai P, Shah AN, Pandya T, Desai P, Pandya T. C-reactive protein, immature to total neutrophil ratio and micro ESR in early diagnosis of neonatal sepsis. IJBAR 2014;5:3646.

3. Shane AL, Stoll BJ. Neonatal sepsis: progress towards improved outcomes. J Infect 2014;68:S24S32.

4. Diaz-Miron J, Miller J, Vogel AM, penyunting. Neonatal hematology. Seminars in pediatric surgery; Elsevier; 2013.

5. Russell ARB. Neonatal sepsis. Paediatr Child Health 2011;21:2659.

6. Shane AL, Sánchez PJ, Stoll BJ. Neonatal sepsis. The lancet 2017; 390(10104):177080.

7. Töllner U. Early diagnosis of septicemia in the newborn. Eur J Pediatr 1982;138:3317.

8. Rodwell RL, Leslie AL, Tudehope DI. Early diagnosis of neonatal sepsis using a hematologic scoring system. J Pediatr 1988;112:761-7.

9. El-Wakeel M, El-Kassas G, Fathy G, El-Wakkad A, Sebaii $\mathrm{H}$, El-Zayat S, dkk. Diagnostic and prognostic values of high sensitive c-reactive protein, tumor necrosis factor and interleukin-1 $\beta$ in neonatal sepsis. Aust J Basic Appl Sci 2012;6:2248.

10. Cosar H, Yilmaz O, Temur M, Ozun O, Bulut Y. Relationship between Early-Onset Neonatal Sepsis and Red Blood Cell Distribution Width (RDW). J Hematol Thrombo Dis 2017;5:2.

11. Liestiadi DEF, Azlin E, Nafianti S. A hematologic scoring system and C-reactive protein compared to blood cultures for diagnosing bacterial neonatal sepsis. Paediatrica Indones 2017;57:705.

12. Adib M, Bakhshiani Z, Navaei F, Fosoul FS, Fouladi $S$, Kazemzadeh H. Procalcitonin: a reliable marker for the diagnosis of neonatal sepsis. Iran J Basic Med Sci 2012;15:777.

13. Saied DA. Can we rely on the neutrophil left shift for the diagnosis of neonatal sepsis? Need for re-evaluation. Egypt Pediatr Assoc Gazette 2018;66:227.

14. Lippi G, Mattiuzzi C, Cervellin G. Learning more and spending less with neglected laboratory parameters: the paradigmatic case of red blood cell distribution width. Acta Bio Medica Atenei Parmensis 2016;87:323-8.

15. TL Gomella MC, FG Eyal. Neonatology. Edisi ke-6. New York: Mc Graw Hill; 2009.h.4967.

16. Tonbul A, Tayman C, Catal F, Kara S, Tatli MM. Red cell distribution width (RDW) in the newborn: normative data. J Clin Lab Anal 2011;25:422-.

17. Loni R, Sengupta A, Jaganathan G, Singh P. The evaluation of $\mathrm{C}$-reactive protein as a screening tool for neonatal sepsis. I J C P 2016;3:1329-33.

18. Kementerian Kesehatan RI. Data dan Informasi: Profil Kesehatan Indonesia. Jakarta: Kemenkes RI; 2017.

19. Darnifayanti D, Tjipta GD, Rusdidjas R, Lubis BM. Immatureto-total neutrophil ratio as an early diagnostic tool of bacterial neonatal sepsis. Paediatrica Indones 2015;55:153-7.

20. Senthilnayagam B, Kumar T, Sukumaran J, Rao K. Automated measurement of immature granulocytes: performance 
Fouad Hakiem dkk: Hubungan antara nilai CRV, rasio I/T, dan RDW dengan kejadian sepsis neonatorum bayi prematur

characteristics and utility in routine clinical practice. Patholog Res Int 2012 2012:483670. doi: 10.1155/2012/483670.

21. Saleh MA, Kasem YT, Amin HH. Evaluation of neonatal sepsis and assessment of its severity by Red Cell Distribution Width indicator. Egypt J Community Med 2017;35:21-33.

22. Martin SL, Desai S, Nanavati R, Colah RB, Ghosh K,
Mukherjee MB. Red cell distribution width and its association with mortality in neonatal sepsis. J Matern Neonatal Med 2019;32:1925-30.

23. Silva ML, Kamat D. Back to Basics: Red Blood Cell Distribution Width: Clinical Use beyond Hematology. Pediatr Rev 2018;39:204-9. 